\title{
Towards Developing an Integrity Framework in Performance Appraisal System (PAS) in the Malaysian Public Sector: A Preliminary Analysis from Justice and Ethical Perspectives
}

\author{
Norhaslinda Jamaiudin ${ }^{1, *}$, Normala Adnan ${ }^{1}$, Rabi'ah Aminuddin ${ }^{1}$ \& S.M.Abdul Quddus ${ }^{1}$ \\ ${ }^{1}$ Department of Political Science, International Islamic Universiti Malaysia (IIUM), Malaysia \\ *Correspondence: Department of Political Science, Kuliyyah of Islamic Revealed Knowledge and Human Sciences \\ (KIRKHS), International Islamic University Malaysia (IIUM), 10470, P. O. Box 10, 50728, Kuala Lumpur, Malaysia. \\ Tel: 361-966-064. E-mail: linda@iium.edu.my
}

Received: December 29, 2017 Accepted: January 10, 2018 Online Published: January 15, 2018

doi:10.5430/mos.v5n1p37 URL: https://doi.org/10.5430/mos.v5n1p37

\begin{abstract}
The implementation of Performance Appraisal System (PAS) is seen as a strategic move to foster performance-based work culture in the Malaysia's public sector. Embedded in pay-for performance system, the new appraisal system which was first introduced in 1992 establishes linkage between pay system, performance and competencies development. However, the chain tying pay to performance appears to be weak. Massive disappointment signals poor implementation as the appraisal system was overshadowed by inappropriate instrument design, rater error, inaccurate rating, bias assessment, etc. These major setbacks have evoked concern over ethical and fairness in the practices of PAS. Occurrence of problems in the implementation of PAS signified erosion of justice and ethics in the practices of PAS, thus lead to growing demand for integrity-based performance assessment system. This preliminary analysis therefore seeks to examine the relationship between ethic, justice and the practices of PAS in the Malaysia's public sector. Correlation coefficient results disclosed positive association between variables as the instrument used, process employed are moderately associated with ethics and justice dimensions. The appraisal system is likely perceived to be good if fair assessment and ethical supervision were present and vice versa. This study deliberately discusses the aforementioned issues through integrated framework based on organizational justice and work character ethics theories and proposed framework for integrity enhancement in the implementation of PAS. Significantly, this article makes a theoretical contribution towards developing higher integrity capacity which often requires in HRM practice.
\end{abstract}

Keywords: human resource management, performance appraisal system (PAS), justice, ethics and integrity

\section{Introduction}

Integrity is a widely ingrained concept in organizational practices. There appears to be no consensus in literature on the meaning of integrity and what does it entails (Monga, 2016) but the term regularly been associated with transparency, accountability that embraces multiple dimension of ethically and morally sounds practices (White \& Lean, 2008; Muhamad Hafiz, 2015 and Monga, 2016). Over the years, demand for integrity-based management has increased under recent public sector reforms that underscore ethical and morally sound practices in management. The needs for ethical management has elevated ever since Performance Management System (PMS) came into force (Winstanley \& Smith, 1996; Bruijn, 2002 and Plant \& Ran, 2009). In the case of Malaysia, support for ethical management has steadily increased through the implementation of National Integrity Plan (NIP) which calls for the enculturation of integrity in the Malaysian public sector. This integrity movement was first initiated by former Prime Minister, Abdullah Ahmad Badawi in 2004 and substantial interest on NIP continues with the second phase of NIP (2009-2013) and the third phase of NIP under the leadership of Najib Abdul Razak (IIM, 2014). Such initiatives led to the establishment of 900 integrity units in various government agencies to date (The Star, 2017). There are six integrity targets outline in the NIP, and cultivating integrity in the Malaysia's public sector is one of the aims. Integrity in the public sectors concentrates on few aspects: minimizing corruption and efficient administration of human resources. Human resource in this context focuses on improving employees' performance through 
performance management agenda. Cultivating performance-based culture and integrity inevitably comes together in quest for having competent, honest and trustworthy employees in the public sector.

Managing employees' performance is done through the implementation of performance appraisal system (PAS). This merit-based assessment marked a significant moved from traditional assessment to performance-based assessment and serve as an important tool in various management decision making. The PAS is introduced on several grounds, firstly, it helps employees on career advancement. Secondly, it offers more opportunity for promotion. Thirdly, it determines the eligibility for salary movement. Finally, it establishes a just system that acknowledges the staff by giving out awards. Apart from that, this tool is used to identify the needs for training for improvement of job performance (JPA Pekeliling Perkhidmatan 4, Lampiran A2, 2002). Those designated objectives could be materialized if fair procedures, just rewards and ethical supervision are properly addressed. Having fulfill those mentioned criteria in HRM practices would contribute to increase employees support to organizational change (Roldell \& Collquit, 2009) and increase job and pay satisfaction, organizational commitment, and trust (Ilgen et al., 1979; Colquitt et al., 2001 and Cohen-Charash \& Spector, 2001 Lambert, Hogan \& Griffin,2007; Farndale, Hailey \& Kelliher (2011).

Malaysian experience reveals that the attainments of such goals were far-fetched. Countless of problems arises hampered the effectiveness of performance appraisal system. Such scenario led to increasing demand for fair appraisal system. Calling for justice and sound ethical appraisal practices is apparent and demand for integrity-based appraisal system is growing. On this note, large scale-attention is devoted to increase sense of integrity in organizational practices by embedding vital values into human resources management practices. This article seeks to analyze the increasing demand of ethical and fair approaches in personnel management, particularly in PAS. To state the case clearly, study identifies the antecedent factors which inflame the need for sound ethical and justice in PAS. Correlation between appraisal system, justice and ethical dimensions are statistically analyzed and theoretically measured based on organizational justice and work character ethics theories. This, in turn serves as a proposed framework to foster integrity in the implementation of PAS.

\section{Reforms in the Malaysia's Public Personnel Management}

Scale of reforms introduced in public personnel management is pervasive. Reform endeavors to enhance the effectiveness and efficiency of Malaysia's civil service public delivery. The New Public Management (NPM) principles has remarkably transformed Malaysian public sector into a goal-driven institution. The emergence of PMS has led to the advancement in performance management agenda through the setting of performance objectives at organizational, group and individual levels (Winstanley, 2000). In the case of Malaysia, recent PMS model witnessed the launch of government transformation programme that holistically addresses organizational and individual performance (Xavier, 2013). Transforming individual performance to a higher level indeed has become the focal point. A strategic reform in the public personnel therefore is taking place and reform is directed towards merit enhancement, thus linking performance with competency development, hence these two are closely associated (Spencer \& Spencer, 1993). Such practice was enunciated through the implementation of pay-for performance system. This process starts with the setting of performance expectations and is followed with performance coaching, performance review and appraisal. This provides clear direction to the employees in terms of effort, tasks and quality under which is to be delivered (Rao, 2004) and subsequently, improves employee performance towards pre-determined goals as set by the organization (Costelli, 1994 \& Bacal, 1999).

Recent management paradigm has brought profound changes in the Malaysia's Public Service Department (PSD). The most prominent is the implementation of PAS that signifies a major shift from seniority-based assessment. In 1990s a remuneration policy which centered on performance management was introduced. Performance and competency dimensions have been integrated into the New Remuneration System (NRS) since 1992 and improved later under the Malaysian Remuneration System (MRS) in 2001. Embedded in pay for performance system, the MRS introduced three components in appraisal system; Annual Work Target (AWT), Competency Level Assessment (CLA) and Performance Appraisal System (PAS). The system not only assessing employees' performance but it fosters skill development through competencies framework. These three components were revised in 2012 that saw the abolishment of CLA as one of the component in PAS. Nevertheless, PAS remain as a supporting tool directed towards employee development.

Embracing this new approach without adequate knowledge and resources would invite more problems as experienced by many countries including Malaysia. The MRS encountered number of problems, and the appraisal system had been lamented due to poor instrument design and weak implementation. Mounting disappointments were 
expressed by employees due to inappropriate methods of assessments, rater error and inadequate performance feedback, inaccurate rating, bias assessment etc (Arzmi, Wood, \& Morris, 2004; Shukran, 2006; Rusli Ahmad, 2012; Rusli Ahmad \& Surena Sabil, 2012, Haslinda \& Abraham, 2012). Discrepancy and deficiency in conducing the appraisal process such as poor setting of AWT and inadequate performance feedback were among shortcomings identified in the implementation of the MRS. Study by Dev Kumar (2005), reveals that 93 percent of officers expressed the need for rater training, hence rater's skill and motivation in conducting the appraisal had tremendous impact on the entire process of appraisal system. Having fair and ethical supervision are vital to minimize occurrences of malpractices in the implementation of PAS (Haslinda \& Abraham, 2012), thus perceived justice could be tremendously improved. Perceived justice significantly influenced employees' acceptance and satisfaction in PAS (Aziz Yusof, 2009; Thiyagarajan, 2011; Mazlan, 2012). Figure 1 presents the antecedent factors that draws attention for integrity framework in the practices of performance appraisal system.

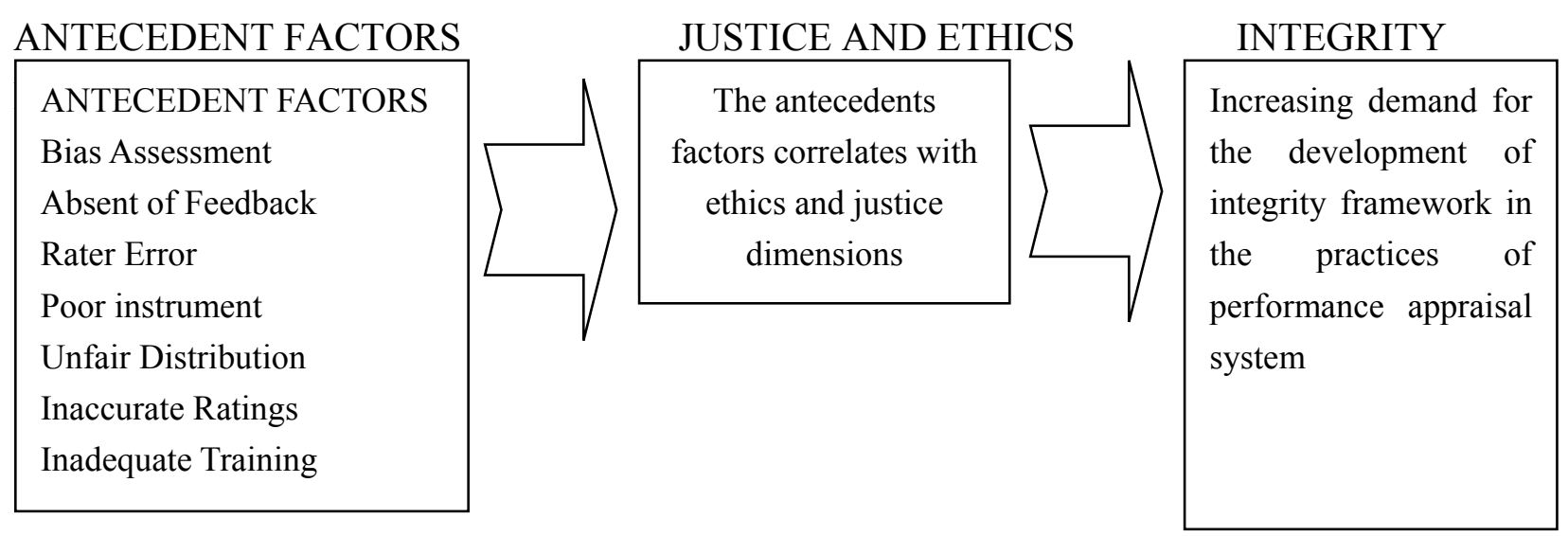

Figure 1. The Relationship between Antecedent Factors, Justice and Ethics in PAS

\subsection{Justice and Ethical Concerns in the Practice of PAS}

The whole scenario signifies that a strong foundation of personal assessment system needs to be reinstituted through ethics and justice dimensions. These normative criteria are deemed important in array of human resources practices (Plant \& Ran, 2009). In the context of performance appraisal, an ethical approach helps performance evaluators to assess employees objectively and accurately. Therefore, having an adequate opportunity to observe employees' performance over the assessment period, having an evaluator who possesses judgment skills and ability to communicate feedback, having a process that is free from judgmental bias, and setting clear objectives and goals have been identified as important criteria for ethical performance appraisal (Sillup \& Klimberg, 2010). In essence, the presence of ethical management practices can eventually lead to a variety of desired outcomes (Pucetaik, Lamsa, \& Novelskaite, 2010).

Unfair and unethical practices has led to the arising concern on integrity of the system hence employees' performance were not objectively assessed. Fairness in this context, reaffirms the importance of valence of outcomes, adherence to rules, satisfaction with supervisor and fair processes in appraisal practices (Cohen-Charash \& Spector,2001; Thurston \& McNall, 2010). Study by Farndale, Hailey \& Kelliher, (2011) found that high commitment performance practices such as greater involvement by employee in setting the target, frequent opportunities to discuss performance and feedback significantly influence employees' perceived level of justice. Fairness therefore, perceived to be an important criterion in judging its effectiveness in an organization with different affective consequences towards employees' attitude and behaviour (Erdogan, 2002; Thurston Jr \& McNall, 2010). Justice in this context can be conceptualized into three dimension notably procedural justice, distributive justice and interactional justice. Concern over justice substantially brought ethical dimension into the limelight as these two are related (Singer, 2000; Newman, 1993). Ethical approach helps performance evaluators to assess employees objectively and accurately (Sillup \& Klimberg, 2010). 


\section{Methodology and Results}

\subsection{Research Instrument and Sampling}

The study employed quantitative techniques to measure correlation between variables namely practices of PAS, justice and ethics. Questionnaires were distributed to one of the public agencies in Malaysia. It comprises of four sections namely demographic, justice and ethical dimensions and practices of PAS. Guided by organizational justice and work character ethics theories, nine items were developed to measure PAS practices, 19 items for justice dimensions encompassing procedural, distribution and interactional justice dimensions and seven items were design to measure the ethical dimension. Employees feedbacks were assessed using five likert scaling ranging from strongly disagree (1) to strongly agree (5). Internal consistency test is conducted to measure the reliability of the research instrument as the coefficient alpha provides a good estimate of reliability (Nunally, 1967). The reliability coefficient for all three constructs was $.875, .913$ and .883 for PAS, justice and ethical constructs respectively. This is an acceptable level for internal reliability (Cramer, 1994).The convenience sampling techniques was used and 550 questionnaires were administered to one of the public agencies in Malaysia and 412 questionnaires are used in data analysis. The response rate is 74.9 percent and this percentage exceeds the minimal level of acceptable response rate (Babbie, 1999).

\subsection{Demographic Data}

Approximately, out of 412 respondents, 75.4 percent are male and 24.6 percent are female respondents. In terms of service group 88 percent are from support group and less than 15 percent come from the professional and management group. Meanwhile, 42 percent of the respondents have been serving the institution for 1 to 5 years, 16.7 percent between 11 to 15 years and 30.7 percent of respondents have been working for more than 16 years. Their duration of service signifies their level of understanding and awareness on the issues concerning the practices of PAS.

\section{Discussion}

A descriptive statistical analysis in the form of mean, standard deviation, minimum-maximum values and correlation is used to measure variables under studies and the result is shown in table 1.

Table 1. Descriptive Statistics of Mean Scores, SD, Min-Max Values and Correlation for Justice, Ethics and Practices of PAS

\begin{tabular}{lllcccccc}
\hline Variable & $n$ & Mean & SD & Min & Max & 1 & 2 & 3 \\
\hline 1. JUSTICE & 412 & 3.696 & 0.511 & 1.74 & 5.00 & 1 & .719 & .673 \\
2. ETHICS & 412 & 3.756 & 0.593 & 1.00 & 5.00 & .719 & 1 & .576 \\
3. PAS & 412 & 3.698 & 0.609 & 1.00 & 5.00 & .673 & .576 & 1 \\
\hline
\end{tabular}

$n=412$

**. Correlation is significant at the 0.01 level (2-tailed).

Notes: $1=$ strongly disagree, $2=$ disagree, $3=$ neutral, $4=$ agree and $5=$ strongly agree

Table 1 shows the descriptive statistics for all constructs measure in the questionnaire. For all three constructs, on a scale one to five, majority of respondents choose scale 3 and 4 as the most preferable answer with mean 3.69 ( $\mathrm{SD}=$ $0.511)$ for justice, $3.75(\mathrm{SD}=0.593)$ for ethics and mean $3.69(\mathrm{SD}=0.609)$ for PAS construct. For justice construct, there exist enough evidence to say that the assessment as a whole met justice requirements. However, the minimum and maximum values signifies the opposing views which can be explained as unfair practices in PAS based on individual experiences. Similarly, the average mean value for ethical dimension implies that assessor in general has demonstrated a moderate level of work character ethics in appraisal, albeit few failed to do so. Finally, responses obtained for PAS construct reveals that varied respondents' opinion on the practices of PAS. The minimum score of 1.00 indicates that the implementation of PAS was not fully adhered to the right practices in which ethical and justice dimension was partially unmet.

Pearson correlation analysis is performed to determine the association between ethics, justice in the context of PAS. This analysis calls for understanding the direction of the association, the degree of association and its strength 
(Creswell, 2005). As shown in the table, the practices of performance appraisal system are positively correlated with justice and ethical dimensions at .673 and .576 respectively. As such, the practice of PAS is moderately associated with justice and ethics. On top of that justice and ethics are highly correlated at .719, thus confirms the relationship between these two as explained by Singer (2002). Positive and significant relationship between these variables signifies the importance of justice and ethics in appraisal system. The right process and procedure follow in the implementation would strengthen perceived justice and ethics in the practices of PAS. In contrast, flaws in the implementation of PAS would produce the opposite outcomes.

Therefore, it is worth noting that the instrument used and the process followed must be properly done if justice and ethical practices of appraisal system is to be upheld. Due emphasis on these elements in appraisal practices is indispensable for effective implementation of PAS and to many other positive outcomes in organizations. Study by Thurston Jr and McNall (2010) confirms that justice perception of performance appraisal practices has influenced employees' reactions toward their work, supervisor and the organization as a whole. It also produces satisfaction both in job and organizational-related matters. The research findings therefore reaffirm and predicate the importance of justice and ethics in the implementation of PAS in the Malaysian context and presumed these two dimensions as pre-conditional factors for enculturation of integrity in PAS.

\subsection{Towards Developing Integrity in the Practices of Performance Appraisal system (PAS): An Integrated Framework of Analysis.}

Flaws in the implementation of PAS have exacerbated disappointment over the system. Apprehension towards the appraisal system mirrored the unsuccessful implementation of PAS since inception. Apparently, inadequate recourses, poor understanding, weak employees' commitment, rater error, absent of adequate training and unfair assessment have bedeviled the system. Those weaknesses have been identified in the NIP. As far as integrity is concern, lack of transparency, system and procedural weaknesses, etc are among factors that lead to the deterioration of integrity (NIP, 2004). The crux of the problem therefore need to be properly addressed and such calls in line with integrity plan so as to introduce a more effective, rational and fairer evaluation system to evaluate performance of the employee (NIP, 2002) thus support the second target of NIP which is to improve the delivery system in the public service and competency of all civil servants (Hana, 2014).

The NIP set five priorities in its early phase and those integrity targets continues with some modifications in the third phase of NIP. Among those are fighting against corruption, malpractices and abuse of power, increasing efficiency of public delivery system and overcoming bureaucratic red tape, enhancing corporate governance and business ethics, strengthening family institution and finally, improving the quality of life and people's well being (NIP, 2004). This comprehensive plan covers eight components and set different strategies to achieve it. Public administration as one of the components in the NIP sets integrity agenda for the administrative institution. Here the role played by the public sector is crucial in strengthening the principles of transparency, accountability and good governance, thus enhancing integrity of public service machinery. The attainment of these objectives is possible through five strategies namely strengthening the effectiveness of good governance, enhancing the effectiveness of public service delivery system, conducting awareness campaigns to wipe out corruption, malpractices and abuse of power and enhancing integrity, strengthening the administration of justice and finally, strengthening Human Resource Management (HRM).

Numbers of strategies are put forward to embed integrity in HRM. Of particular importance is the need to introduce a more effective, rational and fairer evaluation system to evaluate performance of the employee. These initiatives are critical in order to identify weaknesses, undertake re-evaluation, introduce quality improvement measures, reduce bureaucracy and adopt a more effective approach of continuous evaluation (NIP, 2004). Questions arise as to what are the future standards to comply with for integrity to take place? This article argues that the integrity of PAS could be improved and enhanced via ethical and justice dimensions.

Ethics in this context can be specifically measured based on work character ethics. This derived from ethics management theories which give emphasis on the needs to integrate ethics in management practices. Integrating ethics in decision-making is fundamental because of the following reasons: a) the costs of unethical workplace conduct, b) the lack of awareness of ethically questionable, managerial, role-related acts, c) the widespread erosion of integrity and exposure to ethical risk, d) the global corruption pressures that threaten managerial and organizational reputation, and e) the benefits of increased profitability and intrinsically desirable organizational order (Petrick \& Quinn, 1997). At the end of the day, an organization that suffers from the lack of ethical awareness will encounter various problems such as waste use of resources, decline in motivation among employees and low integrity. 
Exhibiting ethical integrity in management can be explained by four theories of ethics namely system development ethics, virtues ethics, teleological and deontological. Basically, system development ethics theories support continuous improvement of moral progression through the exchange of internal and external resources within and between organizations. This is somewhat similar to the open system framework, a model designed in modern organizational theory. It comprises of three levels, namely personal or individual level, organizational and extra organizational ethics. The second branch of management ethics is virtue ethics theories. They stressed on personal development of noble traits and characters. In recent years, several philosophers have proposed that ethics should pay attention to decision-making by persons of good character that is, a virtuous person. A virtuous person possesses intellectual virtues that enable him to be wise, knowledgeable, capable of understanding, courageous and truthful (Birsch, 2002). Virtue ethics idea descends from the classical Hellenistic traditions represented by Plato and Aristotle in which the cultivation of virtuous traits of character is viewed as morality's primary function (Beauchamp $\&$ Bowie, 2001, p. 33). This theory highlights the importance of a person's intention, inclination and virtue for moral and ethical acts. Good intentions will normally result in beneficial outcomes which in return enhance ethics and integrity in management (Hosmer, 2003, p. 97). In short, the overall system of performance appraisal can function effectively if the system is run by virtuous individuals. A manager with a virtuous character is deemed important in conducting a fair performance appraisal. One of the components of virtue ethics is work character ethics. A good characters must be developed in the workplace. This component of virtue ethics emphasizes the development of noble traits at the workplace especially for managers. In order to maintain good manager-subordinate relations, an appropriate work character ethics is crucial. This includes competency, honesty, fairness, trustworthiness, cooperativeness, supportiveness, etc. In this regard, effective functioning of performance assessment system is only possible if the process is carried out by a virtuous manager (Petrick \& Quinn, 1997, p. 51-53).

The notion of justice has an interesting place in a variety of organizational structures and practices. A vast amount of literature on justice has dominated the study of HRM practices in general and the appraisal system in particular (Greenberg, 1990; Charash \& Spector, 2001; Ambrose \& Cropanzano, 2003; Roch \& Shanock, 2006; Ambrose et al., 2007, Erdogan, 2002; Farndale et al., 2011). Ideally, justice is originated from two management ethics theories namely deontological and teleological ethics theories. These two represent major approaches in philosophical ethics. These normative approach defend basic moral norms by determining 'what ought to be done' in practice and focus on the inherent human desire for justice, liberty, dignity and respect (Beauchamp \& Bowie, 2001, p. 7; Hosmer, 2003, p. 90). Teleology is derived from a Greek term that means outcome or result. The most influential philosophers in this discipline are Jeremy Bentham and J.S.Mill (as cited in Hosmer, 2003, p. 95). Within this stream, teleological ethics thinkers claim that the moral character of actions depends on the simple, practical matter of the extent to which actions actually help or hurt people (White, 1993, p. 4). As such, teleological ethics theories maintain that good ends and/ or results determine the ethical value of actions (Petrick \& Quin, 1997, p. 47).

In contrast, deontological ethics theories focus on means rather than ends. Actions are either right or wrong regardless of the outcome. The word "deontology" relates to the Greek term "deon", which refers to the duties or obligations of an individual, which depend upon the intentions of the person making the decision or performing the act (Birsch, 2002; Hosmer, 2003, p. 97). Immanuel Kant is the most influential of deontological philosophers. Deontological ethics theories maintain that responsibly fulfilling obligations, following proper procedures, "doing the right thing", and adhering to moral standards determine the ethical value of actions (Petrick \& Quinn, 1997). Deontologists believe we should look at the reasoning that precedes the action to determine whether it is good or evil (Birsch, 2002). Ethical behaviour based on deontological principles conforms to principles of justice (Newman, 1993, p. 115). Among the major types of deontological ethics are negative and positive rights theories, social contract theories and social justice theories.

The social justice theory expounds the concept of 'justice' and 'fairness'. Rigorous analysis on organizational justice theory is possible by looking into different forms of justice namely distributive justice, procedural justice and interactional justice. The notion of justice has expanded and evolved into several dimensions. Deeply-rooted in social justice theory, the idea of fairness and justice in the workplace has been developed and adjusted accordingly to fit into organizational functions. Initial concerns of justice as promulgated by social justice theories (distributive theory, equity theory and relative deprivation theory) were derived to test principles of justice in general social interaction and not organizations in particular (Greenberg, 1990). Prior to the development of organizational justice theory, scholars devoted more attention on the issue of distributive justice. Their ideas were much influenced by Adam's work on equity theory. Derived from Adam's equity theory, the distributive justice idea compared the ratio of their perceived work outcome to their own perceived work input (Greenberg, 1990). Distributive justice addresses the outcome or incentives received by employees in return for their efforts and contributions. From the justice point of 
view, the outcome should be equivalent to the input. Considerable attention is given to the allocation of organizational resources. Accordingly, different rules of fair allocation must exist in exhibiting distributive justice.

Inadequacy in distributive justice in a variety of work setting has led to the emergence of procedural justice. Explicit concerns in the process used in determining the outcome have been adequately explained in procedural justice. Outcome decision is contingent upon procedure. As such, fairness in means used to derive at those outcome is vital. In turn, procedural justice contributes to a decision-making context that supports the development of moral intent (Newman, 1993, p. 117). Earliest works were done by Thibaut and Walker. Indeed, Thibaut and Walker empirically examined Rawls's basic premise in their seminal work on procedural justice (Schminke, Ambrose, \& Noel, 1997). Focused on the legal setting process, the study revealed that a just procedure exists when disputants have larger control over the process used to resolve those conflicts (Thibaut \& Walker, 1975). Using control theory, Thibaut and Walker explored that employee involvement in the decision-making process and their control over the outcome influences their perception on procedural justice (Thibaut \& Walker, 1975, p. 89). To explore more on procedural justice Leventhal (1980) generates general guidelines on procedural justice that are more applicable in non-legal settings. As highlighted by Leventhal (1980), several rules for determining the fairness of procedure are consistency, bias suppression, accuracy, correctability, representativeness and ethicality (as cited in Rumold, 2010). Greater understanding on procedural justice can also be found in the works done by Lind and Tyler (1980). Based on a group-value model, they argued that individuals have a desire to be a valuable member of their group and a fair procedure is desirable because that indicates that individuals are valued.

Recent advancement in organizational justice theory has led to the development of interactional justice. The third facet of OJT emphasized the quality of treatment received by employees during the process (Bies \& Shapiro, 1987). Introduced by Bies and Moag (1986), interactional justice has generally been conceptualized as part of procedural justice (Cropanzano \& Greenberg, 1997; Folger \& Konouvsky, 1989; Lind \& Tyler, 1988) (as cited in Ambrose et al., 2007). Perceptions of procedural justice were enhanced only when explanations were believed to be adequately reasoned and sincerely communicated (Greenberg, 1990). This type of justice consists of four dimensions: truthfulness, justifications, respect and propriety (Bies \& Shapiro, 1987). Later, Greenberg has suggested that interactional justice can be divided into two components, namely interpersonal justice and informational justice. Respect and sensitivity of supervision refer to interpersonal justice while informational justice put emphasis on justification of decision made by the supervisor. Focusing on the interaction between employee and supervisor, this dyadic relationship has been further discussed in the exchange theory (Roch \& Shanock, 2006).

The emergence of several dimensions of justice marked the importance of this theory in organizational context. Substantial interest in the issue of fairness the organization has encouraged scholars to conduct rigorous studies and apply the principle of justice in the context of organization. Its effects are so profound especially on employees' behaviour and attitude. Justice research has begun to explore the interdependence of justice perceptions and behaviours (Barclay, 2005). Thus, by using organizational justice theory as a framework of study, a big number of research has been carried out to improve understanding on justice in the various levels of management, especially in HRM. Assessment of fairness in organization can be evaluated from three variables; distributive justice, procedural justice and interactional justice. These prominent types of justice is highly correlated but they produce different effects on employees' attitudes and behaviour (Cohen-Charash \& Spector, 2001; Colquitt, 2001; Colquitt et al., 2001; Thurstun \& McNall, 2010; Greenberg, 1990; Erdogan, 2002; Ambrose et al., 2007, \& Karen \& Till, 2011).

Undoubtedly, this theory provides useful explanation in various organizational phenomena (Greenberg, 1990). The organizational justice theory therefore has been framed to explain the wider role of justice in an organization. This includes the role of fairness in human resource management. Hence, employees' right is secured by justice (Rawls, 1971). Concerns about justice in human resource management are always associated with the application of performance assessment. According to Thurstun and McNall (2010) and Erdogan (2002) justice perception are useful in explaining employees' reactions in a performance appraisal context. Higher justice perception would lead to a high possibility of successful implementation of the assessment process (Rumold, 2010). In this regard, the organizational justice theory provides a holistic view on social interaction and structural forces of the appraisal system.

Figure 2. summarizes multiple theoretical dimensions that conceptually form the integrity standards that can be complied in the implementation of PAS 


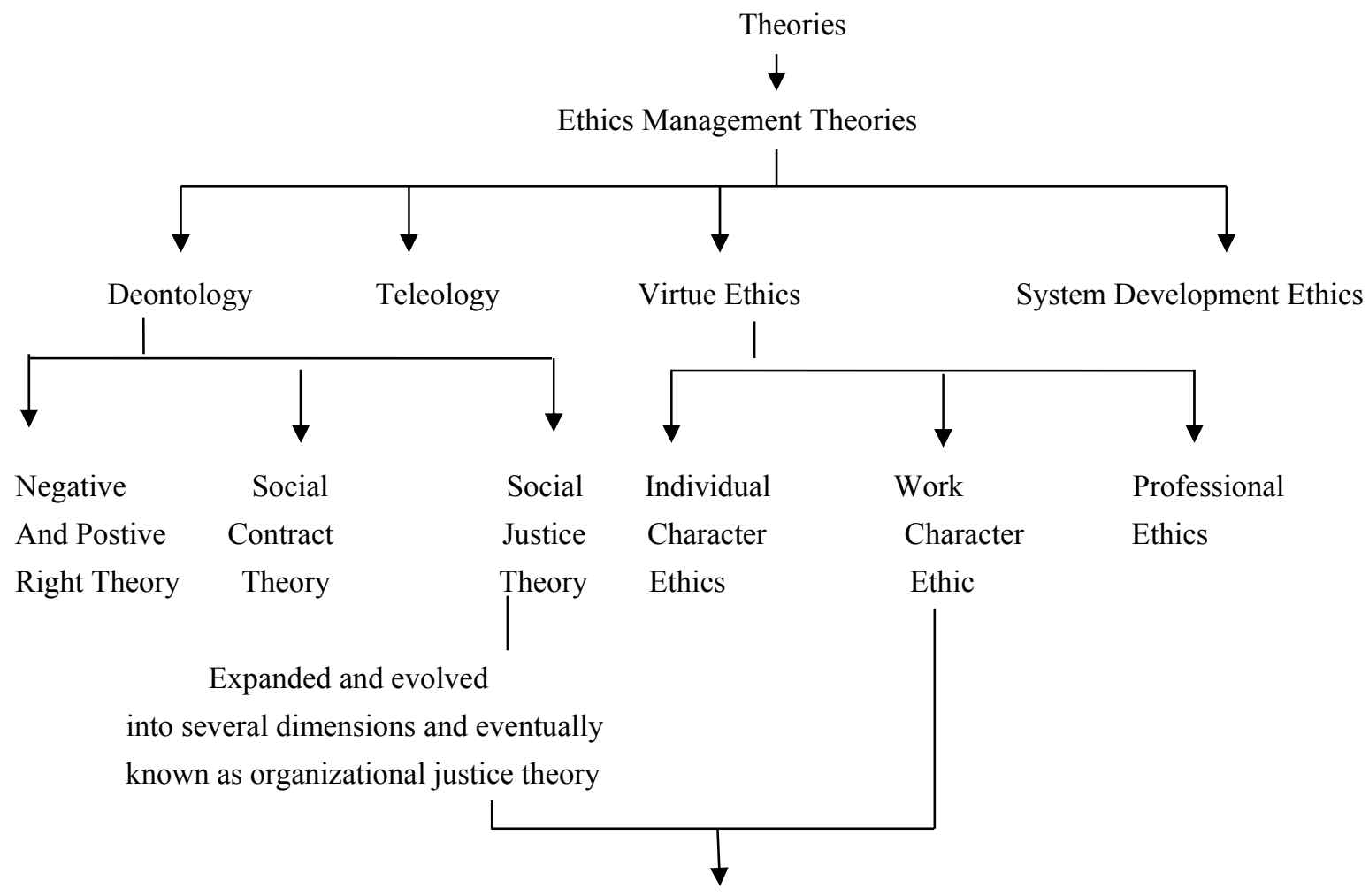

Framework of analysis

Figure 2. An Integrated Framework of Analysis

Figure 2. presents framework of analysis using organizational justice and work character ethics theories. This integrative framework of analysis is proposed to measure the relationship between justice, ethics and integrity in the practice of PAS. It is pertinent to note that these two theories are chosen because it covered the entire facets of appraisal practices in the Malaysian context. By combining justice and ethics, this study intends to raise ethical sensitivity and awareness from the perspective of integrity, thus what constitutes integrity could be properly outlined. This conceptual paper aims to show that the establishment of integrity in the assessment context could be materialized through organizational justice and work character ethics theories. Thus integrity-based management could be established.

\section{Conclusion}

Malpractice in the implementation of PAS has become a long-standing issue in the Human Resource Management (HRM) practices, amid improvement done by PSD. Increasing demand for effective PAS is apparent ever since the implementation of PAS in 1992. Since inception, the implementation of PAS plagued with number of problems ranging from rater error, poor design, bias assessment to unfair distribution of rewards. In short, the implementation of PAS was not well-received and negatively perceived by employees. Research on PAS has extensively been carried out and many have viewed these flaws constraints on the effectiveness of PAS. Poor instrument and weak implementation are among setbacks transpired in the PAS practices. A preliminary quantitative analysis revealed that the practices of PAS indeed positively correlated with the dimensions of justice and ethics. As such, those grievances closely related with justice and ethical dimensions. By minimizing problems, sound ethical practices and justice could be re-instituted and lead to increase effectiveness of PAS.

Sole emphasis on ethics and justice would not suffice. Beyond effectiveness, the PAS should be implemented with high integrity. Justice and ethics are building blocks towards integrity. Integrity indeed, is seen as a holistic framework that would ingrain ethical practices and fairness in PAS. This preliminary analysis is anchored on the argument that the presence of justice and ethics are substantially related with the establishment of integrity in the PAS practices. This argument has extended the role of justice and ethics in HRM practices, hence it would not only 
improve the effectiveness of the system but embolden integrity in human resource management practices.

\section{References}

Ambrose, M.L., \& Cropanzano, R. (2003). A longitudinal analysis of organizational fairness: An examination of reactions to tenure and promotion decisions. Journal of Applied Psychology, 88(2), 266-275. https://doi.org/10.1037/0021-9010.88.2.266

Ambrose, M. L., Hess, R, L., \& Ganesan, S. (2007). The relationship between justice \&attitudes: An examination of justice effects on event and system-related attitudes. Organizational Behavior and Human Decision Processes, 103, 21-36. https://doi.org/10.1016/j.obhdp.2007.01.001

Appelbaum, S.H., \& Mackenzie, L. (1996). Compensation in the year 2000: Pay for performance? Journal of Health Manpower Management, 22(3), 31-39. https://doi.org/10.1108/09552069610125919

Babbie, E. (1999). The basics of social research. Boston: Wadsworth Publishing Company.

Babbie, E. (2002). The basics of social research $\left(2^{\text {nd }}\right.$ ed.). Australia: Wadsworth

Bacal, R. (1999). Performance management. New York: McGraw-Hill.

Barclay, L.J. (2005). Following in the footsteps of Mary from the past can advance organizational justice theory and research. Journal of Management History, 43(5), 740-760.

Beauchamp, T. L., \& Bowie, N. E. (Eds). (2001). Ethical theory and business $\left(6^{\text {th }}\right.$ ed.). New Jersey: Prentice Hall.

Bies, R.J., \& Shapiro, D.L. (1987). Interactional fairness judgements: The influence Of causal accounts. Social Justice Research, 1(2), 199-218. https://doi.org/10.1007/BF01048016

Bies, R.J. (1993). Organizational justice research in the 1990s: Moving in new directions. Social Justice Research, 6(1), 1-4. https://doi.org/10.1007/BF01048729

Birsch, D. (2002). Ethical insights: A brief introduction (2 ${ }^{\text {nd }}$ ed.). Boston: McGraw-Hill Higher Education

Boland, T., \& Fowler, A. (2000). A systems perspective of performance management in public sector organisations. International Journal of Public Sector Management, 13(5), 417-446. https://doi.org/10.1108/09513550010350832

Boukaert, G., \& Haligan, J. (2008). Managing performance: International comparison. London: Routledge.

Boyd, N., \& Kyle, K (2004). Expanding the view of performance appraisal by Introducing social justice concerns. Administrative Theory and Practice, 26(3), 249-278.

Brown, M., Hyatt, D., \& Benson, J. (2010). Consequences of the performance appraisal experience. Personnel Review, 39(3), 375-396. https://doi.org/10.1108/00483481011030557

Bruijn, H. D. (2002). Performance measurement in the public sector: Strategies to cope with the risks of performance measurement. International Journal of public Sector Management, 15(7), 578-594. https://doi.org/10.1108/09513550210448607

Bruijn, H. D. (2007). Managing performance in the public sector ( $2^{\text {nd }}$ ed.). London: Routledge Taylor and Francis Group.

Bryman, A., \& Cramer, D. (1999). Quantitative data analysis with SPSS release 8 for windows: A guide for social scientists. London: Routledge. https://doi.org/10.4324/9780203459621

Cardy, R.L. (2004). Performance management: Concepts, skills and exercises. London: M.E. Sharpe.

Carmines, E.G., \& Zeller, R.A. (1997). Reliability and validity assessment. London: Sage Publications.

Coens, J., \& Jenkins, M. (2000). Abolishing performance appraisal: What they backed and what to do instead. San Francisco: Berrett-Koehler Publishers.

Cohen-Charash, Y., \& Specotr, P.E. (2001). The role of justice in organizations: A meta-analysis. Organizational Behavior and Human Decision Processes, 86(2), 278-321. https://doi.org/10.1006/obhd.2001.2958

Colquitt, J.A. (2001). On the dimensonality of organizational justice: a construct validation of a measure. Journal of Applied Psychology, 86(3), 386-400. https://doi.org/10.1037/0021-9010.86.3.386

Colquitt, J.A., Conlon, D.E., Wesson, M.J., Porter, C.O.L.H., \& Ng, K.Y. (2001). Justice at the millennium: A 
meta-analysis review of 25 years of organizational justice research. Journal of Applied Psychology, 86(3), 425-445. https://doi.org/10.1037/0021-9010.86.3.425

Corbett, B., \& Kenny, B. (2001). Appraisal and learning in a government agency. Journal of the Learning Organization, 8(1), 21-35. https://doi.org/10.1108/09696470110366516

Costelli, S.J. (1994). Effective performance management. New York: Irwin/Mirror press.

Cox, A. (2000). The importance of employee participation in determining pay system effectiveness. International Journal of Management Review, 2(4), 357-375. https://doi.org/10.1111/1468-2370.00047

Creswell, J.W. (2005). Educational research planning, conducting and evaluating quantitative and qualitative research ( $\left.2^{\text {nd }} e d.\right)$. Ohio: Pearson Merrill Prentice hall.

Deci, E.L. (1992). The history of motivation in Psychology and its relevance for management. In Victor H.Vroom \& Edward L.Deci (Eds.), Management and Motivation (pp.9-29). London: Penguin Books.

Dev Kumar. (2005). Performance appraisal: The importance of rater training. Journal of the Kuala Lumpur Royal Malaysian Police College, 4, 1-17.

Duncan, C. (Ed.). (1992). The evolution of performance management: Concepts and Techniques for the 1990s. London: MacMillan Press

Erdogan, B. (2002). Antecedents and consequences of justice perceptions in Performance appraisals. Human Resource Management Review, 12, 555-578. https://doi.org/10.1016/S1053-4822(02)00070-0

Fagelson, D. (2002). Justice as integrity: Objectivity and social meaning in legal theory. Social and Legal Studies, 11(4), 569-588. https://doi.org/10.1177/096466390201100405

Farndale, E., Hailey, V.H., \& Kelliher, C. (2011). High commitment performance management: The roles of justice and trust. Personnel Review, 40(1), 5-23. https://doi.org/10.1108/00483481111095492

Farnham, D, \& Horton, S. (1993). Managing The New Public Services. In Farnham, D., \&Horton, S (Eds), Managing the new public services (pp.112-121). London: MacMillan Press. https://doi.org/10.1007/978-1-349-22646-7

Field, A., Miles, J., \& Field, Z. (2013). Discovering statistics using R. London: Sage Publication.

Fink, L.S., \& Longenecker, C.O. (1998). Training as a performance appraisal improvement strategy. Career Development International, 3(6), 243-251. https://doi.org/10.1108/13620439810234509

Fletcher, C. (1998). Performance management: Perspectives on employees performance. London: International Thomson business

Flint, D.H. (1999). The role of organizational justice in multi-source performance appraisal: theory based applications and directions for research. Human Resource Management Review, 9(1), 1-20. https://doi.org/10.1016/S1053-4822(99)00009-1

Floger, R., \& Skarliski, D.D. (1997). Retaliation in the workplace: The roles of distributive, procedural and interactional justice. Journal of Applied Psychology, 82(3),434-443. https://doi.org/10.1037/0021-9010.82.3.434

Fryer, K., Antony, J., \& Ogden, S. (2009). Performance management in the public sector. International Journal of Public Sector Management, 22(6), 477-498. https://doi.org/10.1108/09513550910982850

Government of Malaysia. (1993). Upholding the integrity of the Malaysian civil service. Kuala Lumpur: Pelanduk Publications.

Government of Malaysia. (2004). National Integrity Plan (NIP). Malaysia: Integrity Institute of Malaysia (IIOM)

Greenberg, J. (1990). Organisational justice: Yesterday, today and tomorrow. Journal of Management, 16(2), 399-432. https://doi.org/10.1177/014920639001600208

Greenberg, J. (2003). Creating unfairness by mandating fair procedures: The hidden hazards of pay for performance plan. Human Resource Management Review, 13, 41-57. https://doi.org/10.1016/S1053-4822(02)00098-0

Greenberg, J. (2004). Stess fairness to fare no stress: Managing workplace stress by promotingorganisational justice. Organizational Dynamics, 33(4), 352-365. https://doi.org/10.1016/j.orgdyn.2004.09.003

Guravan, T.N., \& McGuire, D. (2001). Competencies and workplace learning: Some reflections on the rhetoric and the reality. Journal of Workplace Learning, 13(4), 144-164. https://doi.org/10.1108/13665620110391097 
Halim bin Shafie. (1996). Malaysia's experience in implementing the new performance appraisal system. Public Administration and Development, $341-352$. https://doi.org/10.1002/(SICI)1099-162X(199610)16:4\%3C341::AID-PAD886\%3E3.0.CO;2-N

Halimah Abdul Manaf, Noor Faizzah Dollah \& Muslimin Wallang. (2005). Masalahkeberkesanan sistem saraan baru di kalangan kakitangan awam Malaysia. In Halimah Abdul Manaf, Noor Faizzah Dollah and Muslimin Wallang (Eds.), Pemantapan urus tadbir sektor awam (pp. 203-208). Sintok: Penerbit Universiti Utara Malaysia.

Hana Naz Harun. (2014). IIM moves forward for Integrity. New Straits Times. Retrieved $8^{\text {th }}$ August, 2017 from https://www.nst.com.my/news/2015/09/iim-moves-forward-integrity

Haslinda Abdullah \& Abraham, K.G. (2012). Perception on the performance appraisal system among Malaysian diplomatic officer. The Social Sciences, 7(3), 486-495. https://doi.org/10.3923/sscience.2012.486.495

Heinsman, H., Hoogh, A.H.B., Koopman, P.L., \& Mueijen, J.J.V. (2008). Commitment, control and the use of competency management. Journal of Personal Review, 37(6), 609-628. https://doi.org/10.1108/00483480810906865

Henderson, R.I. (2006). Compensation management in a knowledge-based world (10 ${ }^{\text {th }}$ ed.). New Jersey: Pearson and Prentice Hall.

Heneman, R.L. (1992). Merit pay: Linking pay increases to performance ratings. New York: Addison-Wesley Publishing Company.

Henry, E. (2000). The new pay: Risk and representation at work. In Winstanley, D \& Woodwall, J., (Eds.). Ethical issues in contemporary human resource Management (pp. 172- 188). London: MacMillan Business.

Hood, C., \& Lodge, M. (2004). Competency, bureaucracy and public management reform: A comparative analysis. International Journal of Policy, 17(3), 313-333. https://doi.org/10.1111/j.0952-1895.2004.00248.x

Hooijberg, R., Lane, N., \& Diverse, A. (2010). Leader effectiveness and integrity: Wishful thinking? International Journal of Organisational Analysis, 18(1), 59-75. https://doi.org/10.1108/19348831011033212

Horton, S. (2000b). Competency management in the British civil service. International Journal of Public Sector Management, 13(4), 354-368. https://doi.org/10.1108/09513550010350508

Hosmer, L, R. (2003). The ethics of management ( $4^{\text {th }}$ ed.). Boston: McGraw-Hill Irwin.

Jenkins, M., \& Coens, T. (2000). Abolishing performance appraisal: What they backed and what to do instead. San Francisco: Berrett-Koehler Publishers.

Junaidah Hashim. (2008). The Quran-based human resource management and its effects on organisational justice, job satisfaction and turnover intention. The Journal of International Management Studies, 3(2), 148-159.

Kagaari, J., Munene, J. C., \& Ntayi, J, M. (2010). Performance management practices: Employee attitudes and managed performance. International Journal of Educational Management, 24(6), 507-530. https://doi.org/10.1108/09513541011067683

Karren, R., \& Till, R.E. (2011). Organizational justice perceptions and pay level satisfaction. Journal of Managerial Psychology, 26(1), 42-57. https://doi.org/10.1108/02683941111099619

Kelly, K, O., Angela, S, Y., \& Chong, W. L. (2008). Teacher appraisal and its outcome in Singapore primary schools. Journal of Educational Administration, 46(1), 39-54. https://doi.org/10.1108/09578230810849808

Kessler, R. (2008). Competency-based performance reviews: How to perform employee evaluations the fortune 500 way. New Jersey: Career Press.

Khalid Hafeeza., \& Essmail Ali. (2007). Evaluating organization core competencies and associated personal competencies using analytical hierarchy process. Management Research News, 30(8), 430-547.

Kim, P. S. (2002). Strengthening the pay performance link in government: A case study of Korea. Public Personnel Management, 31(4), 447-464. https://doi.org/10.1177/009102600203100403

Lambert, E.G., Hogan, N.L., \& Griffin, M. L. (2007). The impact of distributive and procedural justice on correctional staff job stress, job satisfaction, and organizational commitment. Journal of Criminal Justice, 35, 644-656. https://doi.org/10.1016/j.jcrimjus.2007.09.001

Leavitt, F. (1991). Research methods for behavioral scientists. United States of America: Wm.C. Brown Publishers.

Leete, L. (2000). Wage equity and employee motivation in non-profit and for profit organizations. Journal of 
Economic Behavior and Organization, 43, 423-446. https://doi.org/10.1016/S0167-2681(00)00129-3

Levy, P.E., \& Williams, J.R. (1998). The role of perceived system knowledge in predicting appraisal reactions, job satisfaction, and organizational commitment. Journal of Organizational Behavior, 19, 53-65. https://doi.org/10.1002/(SICI)1099-1379(199801)19:1\%3C53::AID-JOB826\%3E3.0.CO;2-D

Longenecker, C.O. (1997). Why managerial performance appraisals are ineffective: Causes and lesseons. Career Development International, 2(5), 212-218. https://doi.org/10.1108/13620439710174606

Maimunah, A. (2006). Managing performance training and compensation. Malaysia: Lexis Lexis.

Malek Shah bin Mohd Yusuff. (2005). The public service as a learning organization: The Malaysian experience. International Review of Administrative Sciences, 71(3), 463-474. https://doi.org/10.1177/0020852305056824

Martin, D, E., \& Austin, B. (2010). Validation of the moral competency inventory measurement instrument: Content, construct, convergent and discriminant approaches. Management research review, 33(5), 437-451. https://doi.org/10.1108/01409171011041884

Maund, L. (2001). An introduction to HRM: Theory and practice. New York: Palgrave.

Mazlan Ismail. (2012). Antecedents and outcomes of job satisfaction among Royal Malaysian Police officers: A study at Contingent Police involved with the national key result areas (NKRA) programme. Unpublished master dissertation. University of Malaya. Kuala Lumpur

McAdam, R., Hazlett, A., \&Casey, C. (2005). Performance management in the UK publicsector: Addressing multiple stakeholder complexity. International Journal of Public Sector Management, 8(5), 256-273. https://doi.org/10.1108/09513550510591542

McCain, S. L. H., Tsai, H., \&Bellino, N. (2010). Organizational justice, employees' ethical behaviour, and job satisfaction in the casino industry. International Journal of Contemporary Hospitality Management, 22(7), 992-1009. https://doi.org/10.1108/09596111011066644

Mohd Nizam Mohd Ali, Hashim Abd Jalil \& Sulasteri Abd Hamid. (Eds.). (2013). Inspirasi kepimpinan Polis Diraja Malaysia teras integrity berpasukan. Kuala Lumpur: PDRM.

Moore, R. W., \& Stewart, R. M. (1989). Evaluating employee integrity: Moral and methodological problems. Employee Responsibilities and Rights Journal, 2(3), 1-16. https://doi.org/10.1007/BF01423478

Monga, M. (2016). Integrity and its antecedents: A unified conceptual framework of integrity. Journal of Developing Areas, 50(5). https://doi.org/10.1353/jda.2016.0040

Morris, D., Arzmi Yaacob., \& Wood, G. (2004). Attitudes towards pay and promotion in the Malaysian higher educational sector. Employee Relations, 26(2), 137-150. https://doi.org/10.1108/01425450410511052

Muhammad Hafiz Rusli; Muhamad Azizul; \& Farahwahida. (2015). Integrity system in Malaysian Public Sector: An empirical finding. Procedia Economics and Finance, 28, 260-265. https://doi.org/10.1016/S2212-5671(15)01109-0

Nathan, N.M.L. (1971). The concept of justice. London: MacMillan. https://doi.org/10.1007/978-1-349-01150-6

Newman, K.L. (1993). Procedural justice and ethical decision. Social Justice Research, 6(1), 113-134. https://doi.org/10.1007/BF01048735

Nigro, L., Nigro, F., \& Kellough, J. E. (2007). The new public personnel administration( $6^{\text {th }}$ ed.). Australia: Thomas Wadsworth.

Noreha Hashim. (2007). Memartabatkan integriti dalam penilaian prestasi penjawat awam dibawah SSM: Isu dan cabaran. Pulau Pinang: USM Unit Latihan.

Norhaslinda Jamaiudin. (2012). Strengthening the pay-performance link in government. UK: Lap Lambert Academic Publishing

Nunnally, J.C. (1967). Psychometric theory. New York: Mcgraw Hill

Petrick, J. A., \& Quinn, J. F. (1997). Management ethics integrity at work. London: Sage Publications.

Plant, J., \& Ran, B. (2009). Education for ethics and HRM a necessary synergy. Public Integrity, 11(3), 221-238. https://doi.org/10.2753/PIN1099-9922110302

Poon, J.M.L. (2004). Effects of performance appraisal on job satisfaction and turnoverintention. Personnel Review, 
33(3), 322-334. https://doi.org/10.1108/00483480410528850

Prasad, L, M. (1993). Organisation theory and behaviour. New Delhi: Sultan Chand and Sons Publisher.

Prowse, P., \& Prowse, J. (2009). The dilemma of performance appraisal. Measuring Business Excellence, 13(4), 69-77. https://doi.org/10.1108/13683040911006800

Pucetaik, R., Lamsa, A. M., \& Novelskaite, A. (2010). Building organizational trust in a low-trust societal context. Baltic Journal of Management, 5(2), 197-217. https://doi.org/10.1108/17465261011045124

Rao, T.V. (2004). Performance management and appraisal systems: HR tools for global competitiveness. New Delhi: Response Book.

Rawls, J. (1972). A theory of justice. Clarendon Press: Oxford.

Radnor, Z. (2004). Performance management in the public sector: Fact of fiction? International Journal of Productivity and Performance Management, 53(3), 245-260. https://doi.org/10.1108/17410400410523783

Reychav, I., \& Sharkie, R. (2010). Trust: An antecedent to employee extra-role behaviour. Journal of Intellectual Capital, 11(2), 227-247. https://doi.org/10.1108/14691931011039697

Roch, S. G., \& Shanock, L. R. (2006). Organizational justice in an exchange framework: Clarifying organizational justice distinctions. Journal of Management, 32(2), 299-322. https://doi.org/10.1177/0149206305280115

Rodell, J. B., \& Colquitt, J.A. (2009). Looking ahead in times of uncertainty: The role of anticipatory justice in an organizational change context. Journal of Applied Psychology, 94(4), 989-1002. https://doi.org/10.1037/a0015351

Rodriguez, R.N.T. (2007). Integrity: A systems theory classification. Journal of Management History, 13(1), 74-93. https://doi.org/10.1108/17511340710715188

Rowe, C. (1995). Clarifying the use of competence and competency models in recruitment, assessment and staff development. Journal of Industrial and Commercial Training, 27(11), 12-17. https://doi.org/10.1108/00197859510100257

Rumold, A.K. (2010). An examination of the relationship between a climate for justice and organizational outcome. United States of America: UMI Dissertation Publishing.

Rusli Ahmad. (2012a). Persepsi pekerja terhadap perlaksanaan system penilaian prestasi disektor perkhidmatan pendidikan Malaysia. In Rusli Ahmad \& Shamsiyah Shamsudin., (Eds.). Formula kecermerlangan bekerja dan penilaian prestasi berkesan (pp. 151-164) UNIMAS: Sarawak.

Rusli Ahmad. (2012b). Pengukuran tahap kecekapan pekerja sektor awam di Malaysia: Refleksi dan gagasan berdasarkan perlaksanaan komponen peperiksaan dalam PTK. In Rusli Ahmad \& Shamsiyah Shamsudin., (Eds.). Formula kecermerlangan bekerja dan penilaian prestasi berkesan (pp. 231-245). UNIMAS: Sarawak.

Rusli Ahmad. (2012c). Sistem saran dalam sektor perkhidmatan awam Malaysia dan persepsi pekerja terhadap amalan system pemprosesan maklumat kognitif. In Rusli Ahmad \& Shamsiyah Shamsudin., (Eds.). Formula kecermerlangan bekerja dan penilaian prestasi berkesan (pp. 142-150). UNIMAS: Sarawak.

Rusli Ahmad \& Surena Sabil. (2012). Pemahaman pekerja terhadap konsep penilaian tahap kecekapan dalam SSM: Satu dapatan awal kajian. In Rusli Ahmad \& Shamsiyah Shamsudin., (Eds.). Formula kecermerlangan bekerja dan penilaian prestasi berkesan (pp. 216-230). UNIMAS: Sarawak.

Rusli Ahmad \& Nur Azman Ali. (2004). Performance appraisal decision in Malaysian public service. International Journal of Public Sector Management, 17(1), 48-64. https://doi.org/10.1108/09513550410515565

Rynes, S.L., Gerhart, B., \& Minette, K.A. (2004). The importance of pay in employee motivation: Discrepancies between what people say and what they do. Human Resource Management, 43(4), 381-394. https://doi.org/10.1002/hrm.20031

Schlenker, B, R. (2008). Integrity and character: Implications of principled and expedient ethical ideologies. Journal of Social and Clinical Psychology, 27(10), 1078-1125. https://doi.org/10.1521/jscp.2008.27.10.1078

Scholtes.P.R. (1990). An elaboration on deming's teaching on performance appraisal in Performance Appraisal. In Mclean, G.N., Damme, S.R., Swanson, R.A. (Eds.), Perspective on an quality management approach (pp 2452).US: American Society for Training and Development (ASTD).

Schminker, M., Ambrose, M.L., \& Noel, T.W. (1997). The effect of ethical frameworks on perceptions of 
organizational justice. Academy of Management Journal, 40(5), 1190-1207. https://doi.org/10.2307/256932

Shaw, J., Wild, E., \& Colquitt, J.A. (2003). To justify or excuse? A meta-analytic review of the effects of explanations. Journal of Applied Psychology, 88(3), 444-458. https://doi.org/10.1037/0021-9010.88.3.444

Sheppard, B, H., Lewicki, R, J., \& Minton, J.W. (1992). Organizational justice: The search for fairness in the workplace. New York: Lexington Books.

Shermon, G. (2004). Competency-based HRM: A strategic resource for competency mapping, assessment and development centres. New Delhi: Tata McGraw-Hill Publishing.

Shukran Abdul Rahman. (2006). Attitudes of Malaysian teachers toward a performance-appraisal system. Journal of Applied Psychology, 36(12), 3031-3042. https://doi.org/10.1111/j.0021-9029.2006.00141.x

Siddiquee, N. A. (2006). Public management reform in Malaysia: Recent initiatives and experiences. International Journal of Public Sector Management, 19(4), 339-358. https://doi.org/10.1108/09513550610669185

Siddiquee, N.A., \& Mohd Zin Mohamed. (2007). Paradox of public sector reforms In Malaysia: A good governance perspective. Public Administration Quarterly, 31(3), 284-312.

Siddiquee, N.A. (2010). Managing for results; Lessons from public management reform in Malaysia. International Journal of Public Sector Management, 19(1), 38-53. https://doi.org/10.1108/09513551011012312

Sillup, G.P., \& Klimberg, R. (2010). Assessing the ethics of implementing performance appraisal systems. Journal of Management Development, 29(1),38-55. https://doi.org/10.1108/02621711011009063

Singer, M.S. (2000). Ethical and fair work behaviour: A normative-empirical dialogue concerning ethics and justice. Journal of Business Ethics, 28, 187-209. https://doi.org/10.1023/A:1006299811213

Skarlicki, D.P., \& Folger, R. (1997). Retaliation in the workplace: The role ofdistributive justice, procedural and interactional justice. Journal of Applied Psychology, 82(3), 434-443. https://doi.org/10.1037/0021-9010.82.3.434

Slyvia, R.D., \& Meyer, C.K. (2002). Public Personnel Adminsitration ( $2^{\text {nd }}$ ed.). Philadelphia: Harcourt College Publishers.

Sole, F. (2009). A management model and factors during performance in public organization. Journal Measuring Business Excellence, 13(4), 3-11. https://doi.org/10.1108/13683040911006747

Sulaiman Mahbob, Mohd Nizam Mohd Ali., \& Suzanna Che Moin. (2005). Proceedings of the World Ethics and Integrity Forum 2005 "Building Trust and international Cooperation in Strengthening Integrity. Kuala Lumpur: IIOM.

Svenson, G., \& Wood, G. (2011). A conceptual framework of corporate and business ethics across organizational, structure, process and performance. The Learning Organization, 18(1), 21-35. https://doi.org/10.1108/09696471111095975

Sylvia, R.D. (1994). Public Personnel Administration. California: Wadsworth Publishing Company.

Tan Kwang How. (2011). Human resource management in Malaysia: Theory and practice. Kuala Lumpur: McGraw Hill

Thibaut, J., and Walker, L. (1975). Procedural justice: A psychological analysis. New York: John Wiley and Sons

Thurstun, Jr.P.W., \& McNall, L. (2010). Justice perception of performance appraisal practices. Journal of Managerial Psychology, 25(3), 201-228. https://doi.org/10.1108/02683941011023712

Verbeeten, F. H. M. (2008). Performance management practices in public sector organizations: Impact on performance. Journal Accounting, Auditing and Accountability, 21(3), 427-454. https://doi.org/10.1108/09513570810863996

Verhezen, P. (2008). The (Ir)relevance of integrity in organizations. Public Integrity, 10(2), 133-149. https://doi.org/10.2753/PIN1099-9922100203

Wallace, M.J., \& Fay, C, H. (1998). Compensation theory and practice ( $2^{\text {nd }}$ Ed.). Boston: PWS-Kent.

Wallick, W.G., \& Stager, K.J. (2002). Healthcare managers' roles, competencies, and outputs in organizational performance. Journal of Healthcare Management, 47(6), 390-402. https://doi.org/10.1097/00115514-200211000-00009 
Wanberg, C.R., Bunce, L.W., \& Gavin, M.B. (1999). Perceived fairness of layoffs among individual who have been laid off: A longitudinal study. Personnel Psychology, 52, 59-84. https://doi.org/10.1111/j.1744-6570.1999.tb01813.x

White, T.I. (1993). Business ethics: A philosophical reader. New York: MacMillan Publishing Company.

White, D.W., \& Lean, E. (2008). The impact of perceived leader integrity on subordinates in a work tean environment. Journal of Business Ethics, 81, 765-778. https://doi.org/10.1007/s10551-007-9546-6

Wiese, D.S., \& Buckley, M.R. (1998). The evolution of the performance appraisal process. Journal of Management History, 4(93), 233-249. https://doi.org/10.1108/13552529810231003

Williams, G. J. (1992). Ethics in modern management. New York: Quorum Books.

Wilson, J.P. (1999). The role of learning, training and development in organisation. In Wilson, J.P (Ed.), Human resource development: Learning and training for individuals and organisations (pp. 3-21). London: Kogan Page

Winstanley, D., \& Smith, K.S. (1996). Policing performance: The ethics of performance management. Personnel Review, 25(6), 66-84. https://doi.org/10.1108/00483489610148545

Winstanley, D., \& Woodwall, J. (Ed). (2000). Ethical issues in contemporary human resource management. London: MacMillan Business.

Wittmer, D.P. (2005). Developing a behavioural model for ethical decision making in organizations: Conceptual and empirical research. In Frederikson, H.G., \& Ghere, R.K (Eds.), Ethics in Public Management (pp. 49-69). New York: M.E. Sharpe.

Xavier, J.A. (2013). Managing people: Strategic human resource management initiatives in the public service. In Noore Alam Siddiquee, (Ed.). Public Management and Governance in Malaysia Trends and Transformations (pp. 50-63). London: Routledge Taylor and Francis Group.

Xavier, J.A. (2013). Managing for excellence: Performance management in the public service. InNoore Alam Siddiquee, (Ed.). Public Management and Governance in Malaysia Trends and Transformations (pp. 64-85). London: Routledge Taylor and Francis Group.

Yong, A. (2007). Malaysian human resources management. Kuala Lumpur: Institut Pengurusan Malaysia (MIM)

Young, M., \& Dulewicz, V. (2009). A study into leadership and management competencies predicting superior performance in the British Royal Navy. Journal of Management Development, 28(9), 794-820. https://doi.org/10.1108/02621710910987665

Zhou, Y., Zhang, Y.Y., \& Sanchez, A.M. (2011). Utilitarianism or romanticisim: The effects of rewards on employees' innovative behaviour. International Journal of Manpower, 32(1), 81-98. https://doi.org/10.1108/01437721111121242 